REFLEKSI HUKUM

Jurnal Ilmu Hukum
p-ISSN 2541-4984 | e-ISSN 2541-5417

Volume 4 Nomor 2, April 2020, Halaman 259-280

DOI: https://doi.org/10.24246/jrh.2020.v4.i2.p259-280

Open access at: http://ejournal.uksw.edu/refleksihukum

Penerbit: Fakultas Hukum Universitas Kristen Satya Wacana

\title{
PARADIGMA INTERPRETIF KONSEP PENYALAHGUNAAN KEADAAN (MISBRUIK VAN OMSTANDIGHEDEN) PADA PERJANJIAN KREDIT PERBANKAN
}

\author{
Hanifah Nuraini, Dauri, Thio Haikal A. dan Ricco Andreas \\ Magister Ilmu Hukum Universitas Lampung \\ Korespondensi: hanifahwinartin10@gmail.com
}

Naskah dikirim: 26 Februari 2020|Direvisi: 14 April 2020|Disetujui: 10 Juli 2020

\begin{abstract}
Abstrak
Transaksi bisnis antara pelaku usaha dan konsumen akan selalu dipertemukan dengan suatu perjanjian atau perjanjian yang mengikat para pihak. Khususnya dalam perjanjian kredit perbankan, pihak bank mencetak formulir perjanjian kredit secara massal dan kolektif yang klausulanya disusun sepihak oleh kreditur tanpa keterlibatan debitur. Fenomena ini memberikan pandangan seolah kreditur menggunakan kekuasaannya dengan memanfaatkan ketidakberdayaan debitur untuk kepentingan sepihak sebagai bentuk penyalahgunaan keadaan. Penelitian ini membahas tentangparadigma interpretif penyalahgunaan keadaan pada perjanjian kredit perbankan. Tujuan penelitian untuk mengetahui paradigma konsep penyalahgunaan keadaan kreditur terhadap debitur dalam perjanjian kredit. Metode penelitian yang digunakan adalah penelitian normatif dengan pendekatan konseptual sebagai terobosan atas permasalahan yang terjadi. Hasil penelitian ini menyajikan paparan interpretasi penyalahgunaan keadaan yang seharusnya pada perjanjian kredit perbankan dan harus terkait dengan tindakan nyata yang merugikan debitur baik pada saat melaksanakan perjanjian.
\end{abstract}

Kata-kata Kunci: Paradigma; Penyalahgunaan Keadaan; Perjanjian Kredit.

\begin{abstract}
A binding agreement or contract will always confront business transactions between businesses and consumers. Especially in banking credit agreements, banks make multiple and collective loan agreement forms whose clauses are unilaterally prepared by creditors without debtor involvement. This phenomenon gives perception as if the creditor is using his power by exploiting the power of the debtor for unilateral interests as a form of Undue influence. This study discusses the interpretive paradigm of undue influence in banking credit agreements. The purpose of this research is to find out the paradigm of the undue influence concept of creditors towards debtors in credit agreements. The research method used is normative research with a conceptual approach as a breakthrough for the problems that occur. The results of this study present the exposure to interpretations of the undue influence that should be in banking credit agreements and must be related to concrete actions that harm the debtor both when implementing the agreement.
\end{abstract}

Keywords: Paradigm; Undue Influence; Credit Agreement. 


\section{PENDAHULUAN}

Perjanjian merupakan instrumen penting dalam kegiatan bisnis. Keberadaan perjanjian selain digunakan untuk mempertemukan dan mengikat hak dan kewajiban para pihak juga berfungsi memberikan kepastian dan keamanan dalam transaksi bisnis. Pada era industri saat ini, setiap transaksi bisnis yang mempertemukan kepentingan para pihak dapat dipastikan akan menggunakan perjanjian sebagai payung hukumnya. Perjanjian saat ini pun dapat dikatakan menjangkau aspek hubungan masyarakat yang begitu luas. ${ }^{1}$ Sebab yang mempengaruhinya dapat diamati melalui kesadaran masyarakat akan pentingnya perjanjian dalam setiap perikatan hukum yang mereka lakukan. Mulai dari pinjammeminjam antar perseorangan, jasa perparkiran, penitipan barang, bisnis antar perusahaan hingga hubungan antar negara pun menggunakan perjanjian sebagai dasar pengikatnya.

Esensialitas sebuah perjanjian akan selalu berkenaan dengan kata sepakat, karena tanpa adanya kesepakatan para pihak tentu perjanjian tidak akan terlahir. Kesepakatan adalah keadaan bilamana para pihak menyatakan kehendak masing-masing dalam suatu perjanjian, dan haruslah pernyataan satu pihak berkesesuaian dengan pihak yang lain. Tidak ada kesepakatan bila pernyataan tersebut tidak cocok dan saling berkesesuaian. ${ }^{2}$ Tentunya dalam penyusunan perjanjian, asas kebebasan berkontrak tidak dapat terelakan. Kebebasan berkon- trak berpangkal pada kedudukan kedua belah pihak yang sama kuatnya, memiliki posisi tawar (bergaining position) yang sama, sehingga masing-masing pihak berkedudukan sebagai mitra perjanjian.

Ungkapan teoritis mengenai kebebasan berkontrak telah mengalami banyak perkembangan yang selaras dengan kehendak dan kebutuhan para pihak. Salah satu fenomenanya adalah pada penyusunan perjanjian baku dalam perjanjian kredit perbankan. Perjanjian baku merupakan pembaharuan perjanjian yang hadir ditengah masyarakat modern. Terbukti memberikan solusi yang mempermudah transaksi bisnis dengan tetap berpedoman pada hakikat perjanjian sebagai pondasi kepastian dan keamanan hukum, perjanjian baku kian marak digunakan oleh berbagai lembaga perbankan. Salah satu bentuknya ialah perjanjian kredit yang menaungi transaksi keuangan pada lembaga perbankan, tentu saja harus mengakomodir kepentingan kreditur dan debitur yang mengikatkan hak dan kewajibannya.

Kredit merupakan kegiatan usaha bank yang paling utama dalam menjalankan fungsinya sebagai penghimpun dan penyalur dana masyarakat. Kredit antara lain memfasilitasi permodalan terhadap usaha melalui kredit perbankan, untuk mengembangkan usahanya agar dapat berdaya saing, mengingat kendala yang paling dominan adalah permodalan. ${ }^{3}$ Menurut Pasal 1 angka 11 UU No. 10 Tahun 1998 tentang Perbankan

D.G. Cracknell, Obligation: Contract Law (Old Bailey Press 2003) 5.

Djsadin Saragih, Pokok-Pokok Hukum Perikatan (Airlangga University Press 1985) 2.

Mariane Mogot Limpele, 'Perjanjian Kredit Dengan Jaminan Hak Milik Atas Tanah dan Bangunan Pada Bank Tabungan Negara Cabang Manado Menurut UU No. 4 Tahun 1996 Tentang Hak Tanggungan' (2017) 6 (2) Jurnal Lex Crime 44. 
(selanjutnya UU Perbankan) yang dimaksud dengan kredit adalah:

Penyediaan uang atau tagihan yang dapat dipersamakan dengan itu, berdasarkan persetujuan atau kesepakatan pinjam-meminjam antara bank dengan pihak lain yang mewajibkan pihak peminjam untuk melunasi utangnya setelah jangka waktu tertentu dengan pemberian bunga.

Klausula baku ditetapkan sepihak oleh kreditur dalam formulir perjanjian kredit, hal ini tidak lain dilakukan karena perjanjian kredit sendiri merupakan perjanjian baku yang pembuatannya dilakukan secara kolektif dan massal. Konsekuensi dari perjanjian baku adalah pihak lawan berjanji tidak dapat mengubah atau menambah klausula perjanjian. Kedudukan calon debitur dalam perjanjian kredit dihadapkan pada situasi take it or leave it ${ }^{4}$, bilamana debitur sepakat maka ia dianggap menerima segala ketentuan yang ditetapkan sepihak oleh kreditur.

Ketidakseimbangan posisi dalam perjanjian baku adalah pembaharuan dalam konsep kebebasan berkontrak, risiko dari perjanjian kredit secara sah menjadi tanggung jawab debitur. Namun terkadang keadaan ini memberikan paradigma berbeda, debitur yang merasa keberatan akan menganggap perbuatan kreditur sebagai penyalahgunaan keadaan meskipun secara sah debitur telah menyepakati perjanjian.
Penelitian ini melihat pada dua sisi pandangan mengenai fenomena perjanjian kredit yang dibentuk berdasarkan perjanjian baku, satu sisi memandang pada posisi kedudukan kreditur sebagai pihak yang lebih dominan dan berkuasa untuk menetapkan isi perjanjian sepihak ${ }^{5}$ yang mengakibatkan debitur berpotensi memanfaatkan kedudukan dengan penyalahgunaan keadaan dan di sisi lain memandang adanya pemaksaan kehendak debitur untuk menggunakan fasilitas kredit akibat terdesak masalah finansialnya sendiri.

Penetapan isi perjanjian sepihak menjadi permasalahan menarik untuk dikaji lebih mendalam. Hal tersebut dikarenakan penulis akan menyajikan presepsi masing-masing pihak mengenai penyalahgunaan keadaaan dalam kaitannya dengan pencantuman klausula baku pada perjanjian kredit. Pemaparan ini akan dibahas dengan suguhan paradigma interpretatif sebagai pedoman untuk menelaah kekeliruan pemahaman konsep penyalahgunaan keadaan. Dengan telaah secara interpretif diharapkan penelitian ini mampu menghasilkan konsep penyalahgunaan keadaan yang tepat dan dapat digunakan sebagaimana mestinya tanpa mengurangi atau menghilangkan kepentingan kedua belah pihak.

Jenis penelitian yang digunakan adalah penelitian hukum normatif dengan menggunakan pendekatan conceptual approach ${ }^{6}$ dan statute approach $^{7}$ yang beranjak dari

\footnotetext{
$4 \quad$ Lihat Zuhro Puspitasari, 'Artikel Ilmiah: Analisis Yuridis Perlindungan Hukum Bagi Nasabah Kredit Perbankan dari Penyalahgunaan Keadaan Dalam Perjanjian Baku (Tinjauan Yuridis Undang - Undang Nomor 8 Tahun 1999 Tentang Perlindungan Konsumen)' (Fakultas Hukum Universitas Brawijaya 2014) 4.

5 Lihat Etty Nuryani, 'Klausula Baku yang Tidak Seimbang Dalam Perjanjian Kredit Bank dan Kaitannya dengan Perlindungan Konsumen' (Tesis, Universitas Indonesia 2009).

Peter Mahmud Marzuki, Penelitian Hukum (ed. revisi, Kencana Prenada Media Group 2013) 133. Ibid.
} 
pandangan-pandangan ahli hukum atau doktrin-doktrin. Hal ini dilakukan karena memang peraturan perundang-undangan belum mengatur secara tegas mengenai penyalahgunaan keadaan. Pendekatan konseptual ini akan memberikan gambaran mengenai penyalahgunaan keadaan. Sementara untuk memperoleh gambaran penormaan atas suatu persoalan hukum, maka perlu pula ditelaah menggunakan pendekatan perundang-undangan terkait, seperti KUHPerdata, UU Perbankan, UU No. 8 Tahun 1999 tentang Perlindungan Konsumen (selanjutnya UUPK) dan Peraturan Bank Indonesia. Jenis data ${ }^{8}$ yang digunakan adalah data sekunder yang terdiri dari peraturan perundangundangan terkait penyalahgunaan keadaan, hukum perjanjian, dan aturan terkait sektor jasa keuangan kredit perbankan. Sementara, data sekunder diperoleh melalui literatur yang berkenaan dengan teori, pendapat ahli, dan jurnal mengenai penyalahgunaan keadaan dan kegiatan perkreditan.

\section{PEMBAHASAN}

\section{Doktrin Penyalahgunaan Keadaan dalam Hukum Perdata Indonesia}

Doktrin penyalahgunaan keadaan merupakan hal baru dalam hukum perdata Indonesia. Penyalahgunaan keadaan tidak lahir bersamaan dengan ratifikasi KUHPerdata dari Burgerlijk Wetboek Belanda, namun ia berkembang seiring dengan ragam permasalahan perjanjian di Indonesia. Istilah penyalahgunaan keadaan dalam hukum perdata Indonesia berasal dari padanan misbruik van omstandigheden (civil law) dan undue influence (common law)9:

Some judicial statements ${ }^{10}$ may be read as saying that only active and deliberate abuse of influence amounts to undue influence, but can also be read as stating the primary aim of the doctrine, without excluding relief being given in some cases even if deliberate exploitation has not taken place. That might be justified, for instance, on the basis that it is hard to detect whether the defendant was consciously seeking to exploit the claimant.

Dalam kasus undue influence ${ }^{11}$ harus ditemukan suatu bentuk eksploitasi oleh salah satu pihak atas pihak lainnya yang lebih lemah. Pihak yang berupaya membatalkan perjanjian dengan dalil undue influence harus mampu membuktikan bahwa perjanjian itu tidak jujur, bahwa dirinya tidak bersalah tetapi dirugikan. Pihak lainnya harus membela diri dengan membuktikan bahwa sudah ada nasihat profesional dan independen yang telah diberikan sebelum perjanjian itu disepakati.

The undue influence doctrine responds to the exploitation of a relationship of influence to obtain an undue advantage. ${ }^{12}$ Tidak semestinya dalam suatu perikatan timbul eksploitasi salah satu pihak demi

Lihat Soerjono Soekanto, Pengantar Penelitian Hukum (Rineka Cipta 1986) 11.

Bryan A. Garner (ed), Black's Law Dictionary (9th edn, West Group 2009) 1062.

Hugh Beale, 'Undue Influence and Unconscionability', dalam Andrew Dyson, James Goudkamp and Frederick Wilmot-Smith (eds) Defences in Contract (Hart Publishing 2017) 89.

11 Arthur Lewis, Dasar-dasar Hukum Bisnis penerjemah Derta Sri Widiowatie (Nusa Media 2009) 132.

12 Lihat analisis perkara $R v$ Attorney-General for England and Wales 2003 pada Mindy ChenWishart, 'Legal Transplant and Undue Influence: Lost in Translation or A Working Misunderstanding?’ (2013) 62 (1) International and Comparative Law Quarterly 1-30. 
keuntungannya sendiri. Hal inilah yang mendasari keberadaan dalil penyalahgunaan keadaan, guna mencegah perbuatan tidak terpuji yang merugikan pihak lawan berjanjinya. Selain itu "the balance of judicial opinion, however, seems to be that undue influence involves victimisation and exploitation 13 ". Meskipun belum terdapat karakteristik dalam balutan regulasi, beberapa putusan pengadilan menafsirkan penyalahgunaan keadaan pada perilaku viktimasasi dan eksploitasi yang mengancam dan merugikan salah satu pihak.

Pada mulanya doktrin ini muncul pertama kali di Inggris yang menganut common law system. Ajaran tentang penyalahgunaan keadaan pada saat itu muncul karena Burgerlijk Wetboek memang belum mengaturnya. Eksistensinya muncul semenjak banyak yurisprudensi hakim yang menemukan keadaan tertentu dan dianggap bertentangan dengan kebiasaan, maka hakim memutus perkara tersebut dengan dasar penyalahgunaan keadaan dan membatalkan perjanjian untuk sebagian atau seluruhnya. ${ }^{14}$ Terhadap pendapat yang menggolongkan penyalahgunaan keadaan itu ke dalam 'sebab yang tidak dibolehkan' J.M. van Dunne dan Gr. van den Burght dalam sebuah diktat kursus hukum perikatan bagian III mengajukan keberatan ${ }^{15}$ yang pada intinya menentang pemikiran mengenai pembatalan perjanjian dengan dalil penyalahgunaan keadaan terjadi karena bertentangan dengan unsur kausa yang halal. Van Dunne berpendapat bahwa penyalahgunaan keadaan berhubungan dengan terjadinya kesepakatan. Dengan kata lain menikmati keadaan orang lain tidak menyebabkan isi perjanjian atau maksudnya menjadi tidak dibolehkan (kausa yang halal), penyalahgunaan keadaan menyebabkan kehendak yang disalahgunakan menjadi tidak bebas.

$$
\text { Setiawan mengungkapkan }
$$

bahwa Z. Asikin Kusumah Atmadja dalam ceramah di Jakarta pada tanggal $21 \quad$ November 1985 menyatakan bahwa penyalahgunaan sebagai faktor yang membatasi atau mengganggu adanya kehendak yang bebas untuk menentukan persetujuan antara kedua pihak, Pasal 1320 sub kesatu KUHPerdata. ${ }^{16}$ Setiawan juga mengajukan pendapat Cohen yang menyatakan bahwa tidak tepat menggolongkannya sebagai kausa yang tidak halal (ongeoorloofde oorzaak). Kausa yang tidak halal memiliki ciri yang berbeda, karena tidak berkaitan dengan cacat kehendak. Meskipun pihak yang bersangkutan mendalilkannya sebagai kausa tidak halal. Namun Hakim secara ex officio wajib mempertimbangkan pembatalan perjanjian. Berbeda halnya dengan kehendak yang cacat (wilsgebrek): pernyataan batal atau pembatalan perjanjian hanya akan diperiksa oleh hakim kalau didalilkan oleh yang bersangkutan ${ }^{17}$.

Dasar yang kuat untuk mengkategorikan penyalahgunaan keadaan

\footnotetext{
13 Beale (n 10) 87-110.

14 Henry P. Panggabean, Penyalahgunaan Keadaan (Misbruik van Omstandigheden) Sebagai Alasan (Baru) Untuk Pembatalan Perjanjian (Berbagai Perkembangan Hukum di Belanda dan Indonesia) (Liberty 2001) 41.

15 Lihat Fatmah Paparang, 'Misbruik van Omstandigheden dalam Perkembangan Hukum Perjanjian' (2018) 22 (2) Jurnal Hukum Unsrat 46, 50.

$16 \quad$ Ibid., 51.

17 Ibid.
} 
sebagai salah satu bentuk cacat kehendak ialah berkenaan dengan kebutuhan konstruksi hukum dalam hal seseorang hendak melakukan upaya hukum represif terhadap kerugian yang dideritanya. Penyalahgunaan tidak berhubungan dengan syarat objektif, melainkan lekat dengan syarat subjektif sehingga terkategori cacat kehendak.

Cacat kehendak dalam istilah asing disebut wilsgebreken atau defect of consent. Cacat kehendak merupakan tidak sempurnanya suatu kesepakatan dalam sebuah perjanjian. Apabila kesepakatan dalam perjanjian atau perjanjian tersebut terdapat cacat kehendak, memang sekilas nampak adanya kata sepakat, namun kesepakatan tersebut dibentuk bukan berdasarkan kehendak bebas para pihak. Dengan demikian adanya cacat kehendak tersebut menunjukkan bahwa sebenarnya di dalam perjanjian itu tidak ada kesepakatan. ${ }^{18}$ Hal-hal yang dapat mempengaruhi kata sepakat sebagaimana di atas, tunduk pada pengaturan dalam Pasal 1321 KUHPerdata yang mengatur mengenai cacat kehendak. ${ }^{19}$ Adapun alasan untuk membatalkan perjanjian karena mengandung cacat kehendak yang sebagaimana dikemukakan Pasal 1321 KUHPerdata adalah kekhilafan atau kesesatan (dwaling), paksaan dan penipuan (bedrog).

Asas kebebasan berkontrak teridentifikasi sebagai pedoman para pihak yang bebas menetapkan, membuat dan melaksanakan perjanjian selagi masih dalam koridor Pasal 1320 KUHPerdata dan tidak bertentangan dengan UU, kesusilaan dan ketertiban umum. Makna 'bebas' tidak jarang diartikan sebagai kehendak yang tak terbatas. Dalam artian lain, kehendak yang tak terbatas dapat berakhir pada penyalahgunaan keadaan. Untuk itu penting dipahami bahwa asas kebebasan berkontrak tidak menghendaki kebebasan yang mutlak dan memiliki batasan yang tidak melampaui kedudukan yang seimbang. Hal ini melibatkan doktrin penyalahgunaan keadaan pada kebebasan yang terbatas dalam penggunaan asas kebebasan berkontrak.

Perkembangan yang terjadi dalam hukum perikatan memantapkan penyalahgunaan keadaan menjadi salah satu faktor yang membatasi penerapan prinsip kebebasan berkontrak. Penerapan penyalahgunaan keadaan sebagai faktor yang membatasi adanya kehendak yang bebas dalam pembuatan perjanjian telah diterima Mahkamah Agung antara lain dalam putusan No. 2230K/Pdt/1985 dalam kasus PT. Adamson lawan PT. BSN dan putusan No.2464K/Pdt/ 1986 dalam kasus Hotel Medan Utara lawan Bank Eksport Import Indonesia. ${ }^{20}$ Yurisprudensi berkenaan dengan doktrin penyalahgunaan keadaan merupakan upaya peradilan untuk melindungi pihak yang lemah dari perbuatan sewenang-wenang pihak lain yang secara situasi ataupun

18 Utfiyafina Mardhati H. dan Heru Saputra, 'Penyalahgunaan Keadaan (Misbruik ban Omstandigheden) dalam Perjanjian Asuransi Melalui Telemarketing' (2019) 41 (2) Jurnal Kertha Patrika 95, 100.

19 Fani Martiawan Kumara Putra, 'Paksaan Ekonomi dan Penyalahgunaan Keadaan Sebagai Bentuk Cacat Kehendak Dalam Perkembangan Hukum Perjanjian' (2015) 30 (2) Jurnal Yuridika 232, 236.

20 Ricardo Simanjuntak, 'Akibat dan Tindakan-tindakan Hukum Terhadap Pencantumkan Klausula Baku dalam Polis Asuransi yang Bertentangan dengan Pasal 18 UU 8/1999 tentang Perlindungan Konsumen' (2003) 22 (2) Jurnal Hukum Bisnis 53, 58. 
sosial ataupun jabatan mendominasi dalam memaksa pihak yang lemah untuk tidak mempunyai pilihan lain selain menandatangani perjanjian, dimana akhirnya perjanjian tersebut berakibat kerugian pada salah satu pihak. ${ }^{21}$

Dalam tatanan hukum positif, yurisprudensi merupakan satu dari sekian sumber hukum dan dapat dijadikan acuan bagi majelis hakim dalam memutus perkara. Yurisprudensi juga dapat dikategorikan sebagai rechtvinding ${ }^{22}$ bila dalam ketentuan perundang-undangan belum terdapat pengaturannya. Sampai saat ini dalil penyalahgunaan keadaan tetap diakui di lingkup peradilan Indonesia dan majelis hakim dalam mempertimbangkan kasus serupa akan berpedoman pada yurisprudensi terkait.

Lembaga penyalahgunaan keadaan dalam sistem hukum perdata ironisnya belum dikenal di Indonesia, sehingga dalam penyelesaian sengketa yang bermuatan penyalahgunaan keadaan dalam suatu perjanjian bisnis masih belum memiliki kepastian hukum, karena belum diatur dalam suatu peraturan perundang-undangan nasional (hukum positif). Di samping itu, masih terdapat kesulitan dalam merumuskan karakteristik tentang penyalahgunaan keadaan.

Alasan diakuinya penyalahgunaan keadaan sebagai dasar pembatalan perjanjian dikarenakan beberapa faktor riil yang terjadi di masyarakat memang tidak dapat terhindar dari perbuatan penyalahgunaan keadaan. Maraknya perjanjian yang dibuat dengan ketidaksetaraan posisi berbanding lurus dengan potensi penyalahgunaan keadaan salah satu pihak yang berjanji.

\section{Perjanjian (baku) Kredit Perbankan: Kesengajaan Kreditur atau Kesalahan Debitur?}

Bagi ilmu hukum, paradigma bisa diposisikan sebagai mazhab, namun bisa juga sebagai satu kerangka referensi atau pandangan yang menjadi satu dasar keyakinan atau pijakan suatu teori. Posisi paradigma menjadi penting dalam penelitian ilmu hukum karena akan membawa konsekuensi praktis bagi perilaku, cara berfikir, interpretasi dan kebijakan dalam pemilihan masalah. ${ }^{23}$ Konseptual paradigma bermula dari asumsi-asumsi dasar yang diyakini ilmuwan/peneliti dalam menentukan cara memandang gejala yang diteliti. Hal ini perlu dilakukan agar objek yang menjadi fokus penelitian dapat terarah dan tersistematisasi dengan baik agar menghasilkan output yang bermanfaat dan relevan dengan kebutuhan masyarakat.

Sarantakos mengikuti penggolongan yang dibuat oleh Chua dengan mengklasifikasikan paradigma men

\footnotetext{
21 Ibid.

22 "Penggunaan sumber hukum. rechtsvinding, di dalam konteks hukum positif Indonesia, UU didahulukan dari sumber-sumber hukum lainnya. Di dalam hal ini, jika hendak mencari hukum suatu peristiwa, maka dicarilah terlebih dahulu dalam UU, karena UU bersifat otentik dan tertulis, yang lebih menjamin kepastian hukum. Jika hal peristiwa tersebut dinilai tidak ada dalam UU, maka dilihat di dalam yurisprudensi, dan seterusnya. Dalam menyimpulkan sebuah hukum, maka tidak bisa lepas dari aliran-aliran yang mempengaruhinya. Jika dalam hukum perdata Indonesia terdapat aliran Legisme, aliran Hukum Bebas, dan aliran Rechtsvinding (penemuan hukum)". Lihat Nurmin K Martam, "Tinjauan Yuridis tentang Rechtvinding (Penemuan Hukum) dalam Hukum Perdata Indonesia' (2018) 1 (1) Gorontalo Law Review 77-88. Sulaiman, 'Paradigma Dalam Penelitian Hukum' (2018) 20 (2) Kanun Jurnal Ilmu Hukum 255, 258.
} 
jadi tiga, yaitu; (1) positivist paradigm, (2) interpretivist paradigm, dan (3) critical paradigm. ${ }^{24}$ Paradigma interpretif berasal dari filsafat Jerman yang menitikberatkan pada peran bahasa, interpretasi, dan pemahaman dalam ilmu sosial. 25

Persepsi tentang kenyataan paradigma interpretif berbeda dengan positivistik. Sarantakos juga menyebutkan bahwa penamaan sesuatu atau sesuatu yang diciptakan oleh manusia merupakan produk dari pikiran yang berupa ide, konsep, gagasan dan sebagainya. Sehingga realitas sosial bukan sesuatu yang berada di luar manusia, (not 'out there'), melainkan sesuatu yang sudah inherent dalam pikiran manusia. ${ }^{26}$ Dalam paradigma interpretif ini, kenyataan tidaklah berada di luar sana', tetapi dalam pikiran manusia. Kenyataan itu dialami secara internal, dikonstruksi secara sosial melalui interaksi, dan diinterpretasikan oleh para pelaku atau aktor-aktor dan didasarkan pada definisi yang diberikan pada hal tersebut. ${ }^{27}$

Permasalahan ini mengandung kontra-presepsi terhadap konsep penyalahgunaan keadaan dalam perjanjian kredit perbankan. Paradigma lahir karena adanya perbedaan pandangan dalam menginterpretasikan makna penyalahgunaan keadaan. Pihak debitur menafsirkan penyalahgunaan keadaan sebagai tindakan kreditur memanfaatkan ketidakberda- yaan debitur yang terdesak masalah ekonomi dengan mencantumkan klausula-klausula baku yang membebani debitur. Disisi lain kreditur menafsirkan penerbitan perjanjian kredit yang bersifat baku semata-mata untuk pelayanan yang efektif dan efisien tanpa menyalahgunakan keadaan karena debitur tetap diberi kesempatan untuk mempelajari isi perjanjian dan menolak bila tidak berkenan (selaras dengan teori take it or leave it ${ }^{28}$ ).

Realitas yang diilhami debitur mengenai penyalahgunaan keadaan bertumpu pada keberadaan klausula baku dalam perjanjian kredit yang bertentangan dengan ketentuan Pasal 18 UUPK. Pasal ini mengatur tentang macam-macam klausula baku yang dilarang dicantumkan dalam perjanjian karena dianggap berpotensi dapat merugikan salah satu pihak.

Debitur merasa tindakan kreditur mencantumkan klausula baku yang mengandung unsur-unsur dalam Pasal 18 UUPK adalah suatu penyalahgunaan keadaan. Dasar kuat yang mendasari interpretasi tersebut terletak pada kedudukan kreditur yang lebih unggul secara ekonomis, membuat posisi debitur lemah dan tidak memiliki daya upaya untuk menegosiasikan perjanjian kredit sehingga terkesan cenderung lebih memprioritaskan kepentingan kreditur ketimbang kepentingan kedua belah pihak.

\footnotetext{
24 Arif Hartono, 'Multi Paradigma Dalam Penelitian Akuntansi; Suatu Tinjauan Konsep' (2012) 10 (1) Jurnal Ekulilibrium 60, 61.

25 Antonius Singgih Setiawan, 'Penggunaan Metode Kuantitatif Adalah Paradigma Positivist' (2014) 12 (1) Jurnal Buletin Ekonomi 15. Hartono (n 24) 64.

T.O. Ihromi, 'Paradigma Baru bagi Pengkajian Masalah Wanita dan Jender dalam Antropologi' (1999) 60 Antropologi Indonesia 50, 54.

28 Lihat penjelasan mengenai teori take it or leave it perjanjian baku pada Agus Satory, 'Perjanjian Baku dan Perlindungan Konsumen dalam Transaksi Bisnis Sektor Jasa Keuangan: Penerapan dan Implementasinya di Indonesia' (2015) 2 (2) Padjadjaran Journal of Law 269, 276.
} 
Penyalahgunaan keadaan dengan keunggulan ekonomis juga diduga sebagai dampak dari kerugian yang dialami debitur dari klausula dalam perjanjian kredit. Praduga debitur terhadap indikasi perilaku penyalahgunaan keunggulan ekonomi pada perjanjian a quo adalah wujud refleksi dari apa yang diamatinya sebagai kenyataan dan apa yang dipikirkannya.

Lain halnya dengan interpretasi kreditur, secara formil ketentuan mengenai perjanjian kredit dimuat dengan klausula baku adalah syarat yang ditetapkan oleh Surat Bank Indonesia No.03/1093/UPK/KPD tanggal 29 Desember 1970 yang ditujukan kepada segenap Bank Devisa saat itu, pemberian kredit diinstruksikan harus dibuat dengan surat perjanjian kredit sehingga perjanjian pemberian kredit tersebut sampai saat ini disebut perjanjian kredit. Penyusunan perjanjian kredit dengan format baku bagi kreditur adalah wujud dari kepatuhan hukum dan bukan sebaliknya.

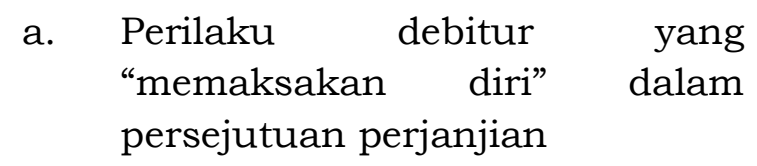

Masyarakat khususnya debitur seringkali mengajukan permohonan kredit tanpa mempertimbangkan dampak yang diderita karena terdesak oleh kebutuhan ekonomi. Bisa saja dikatakan bahwa memang ada faktor keunggulan ekonomi kreditur dalam transaksi perjanjian kredit yang memuat klausula baku, dan dapat dibenarkan bahwa beberapa klausula tersebut berpotensi membebani debitur karena cenderung memihak pada kepentingan kreditur. Lalu pertanyaannya apakah unsur tersebut dapat dikategorikan sebagai penyalahgunaan keadaan? Perlu dicermati bahwa keadaan seperti ini harus ditelusuri secara mendetil dari proses awal perjanjian sampai pelaksanaannya.

Diawali dari keinginan kuat debitur yang membutuhkan dana cepat untuk permasalahan finansialnya guna memenuhi keperluan baik terdesak atau a priori. Kredit menjadi solusi mutakhir untuk menuntaskan persoalan tersebut. Kredit banyak disediakan oleh lembaga-lembaga pembiayaan di Indonesia maupun mancanegara, namun komoditi kredit masyarakat mayoritas jatuh kepada lembaga keuangan perbankan. Tahapan perjanjian kredit perbankan pun pada umumnya sama seperti tahapan perjanjian baku, hanya saja terdapat beberapa prosedur tambahan yang harus dijalankan guna menghindari risiko-risiko finansial mengingat bank adalah lembaga keuangan dengan high risk. Menurut Kasmir ${ }^{29}$, tahapan prosedur pemberian kredit terdiri dari: 30

1) Pengajuan berkas, dalam hal ini pemohon kredit mengajukan permohonan kredit dengan melampirkan berkas-berkas lain yang dibutuhkan.

2) Penyelidikan berkas pinjaman, dalam hal ini menyelidiki kelengkapan dan keabsahan berkas, untuk memenuhi syarat kredit yang sesuai.

3) Wawancara, yaitu penyelidikan

29 Kasmir, Manajemen Perbankan (cet. 2, Rajagrafindo Persada 2008) 115-119.

30 Vanya Shauma Harumita, 'Pentingnya Validitasi Data Pengajuan Kredit Pensiun Pada PT Bank Rakyat Indonesia Tbk: Kantor Cabang Kusuma Bangsa Surabaya' (Makalah, Fakultas Vokasi Universitas Airlangga 2015) 17-19. 
kepada calon peminjam dengan langsung berhadapan melakukan sesi tanya-jawab.

4) On the spot, yaitu pemeriksaan langsung dengan meninjau berbagai objek yang akan dijadikan usaha ataupun jaminan yang kemudian disesuaikan dengan hasil wawancara.

5) Keputusan kredit, yaitu menentukan apakah kredit diberikan atau ditolak. Biasanya keputusan kredit yang akan diumumkan mencakup jumlah uang yang diterima, jangka waktu kredit, biaya-biaya yang harus dibayar dan waktu pencairan kredit.

6) Penandatangan perjanjian kredit. Kegiatan ini merupakan kelanjutan dari diputuskannya kredit, maka sebelum kredit dicairkan terlebih dahulu calon nasabah menandatangani perjanjian kredit yang berisi klausul-klausul mengenai keputusan kredit sebelumnya, mengikat jaminan dengan hipotik dan surat perjanjian atau pernyataan yang dianggap perlu. Penandatangan dilaksanakan melalui bank dengan debitur secara langsung atau di hadapan notaris.

7) Realisasi kredit, diberikan setelah penandatanganan perjanjian kredit dan surat-surat yang diperlukan dengan membuka rekening giro atau tabungan di bank yang bersangkutan.

8) Penyaluran atau penarikan dana yaitu pencairan fasilitas kredit dilakukan melalui rekening sebagai realisasi pemberian kredit dan dapat diambil sesuai ketentuan dan tujuan kredit yaitu secara bertahap atau sekaligus.
Penyelenggaraan perjanjian kredit pada dasarnya memiliki prosedur yang berbeda-beda di setiap lembaga keuangannya termasuk lembaga keuangan pada beberapa bank. Namun garis besar penyelenggaraan pemberian kredit setidaknya mensyaratkan prosedur seperti yang terurai di atas meskipun dengan cara dan tata urutan yang berbeda. Setidaknya prosedur pemberian kredit secara umum adalah mengenai know your customer, yang bilamana tidak terlaksana maka bank tidak akan berani memberikan sejumlah pinjaman kepada debitur karena akan cenderung memiliki tingkat resiko tinggi.

Berbicara mengenai penyalahgunaan keadaan dalam suatu perjanjian maka kita tidak bisa terlepas dari unsur cacat kehendak yang erat sebagai syarat utama penyalahgunaan keadaan. Bank dalam memberikan pelayanan permohonan kredit tentu memiliki prosedur berdasarkan standar yang ditetapkan Bank Indonesia. Seperti yang dijabarkan di atas mengenai prosedur pemberian kredit, terdapat tahapan dimana pihak bank melakukan sesi pemeriksaan dan konsultasi tatap muka dengan calon debitur untuk memastikan kesiapan debitur mengadakan perjanjian kredit.

Selanjutnya perjanjian kredit yang diserahkan pada debitur meskipun bersifat baku tetapi juga mengandung keputusan-keputusan kredit (dalam hal ini keputusan a quo bersifat khusus) yang ditetapkan pihak bank setelah menganalisis persiapan calon debitur dan pihak debitur wajib diberikan kesempatan untuk mempelajari atau meminta 
penjelasan isi perjanjian kredit terlebih dahulu sebelum menandatanganinya. Cacat kehendak dapat terjadi bila prosedur-prosedur khusus itu tidak dilaksanakan oleh kreditur yang juga berarti bahwa kreditur telah melakukan perbuatan penyalahgunaan keadaan.

Ketika unsur cacat kehendak tidak dapat dibuktikan tetapi debitur tetap mendalilkan kerugian akibat beban yang harus ditanggungnya, maka hal ini adalah sebuah kekeliruan. Beban yang diderita debitur adalah bentuk konsekuensi dari pelaksanaan perjanjian kredit. Sepatutnya sebelum memutuskan untuk melakukan pinjaman bank, debitur harus memastikan kesanggupan melunasi pinjamannya. Kasus seperti ini dapat dikategorikan sebagai perilaku debitur yang memaksakan diri dan gegabah mengajukan permohonan kredit karena desakan finansial.

b. Penyalahgunaan keunggulan ekonomi kreditur dengan memanfaatkan ketidakberdayaan debitur

Berbagai keluhan tentu dirasakan oleh debitur dalam pelaksanaan perjanjian kredit perbankan salah satunya akibat pencantuman klausula baku. Klausula tersebut ditetapkan sepihak oleh kreditur tanpa memperhatikan atau mempertimbangkan keadaan debitur. Secara das sollen, eksistensi para pihak dalam perjanjian baku diibaratkan dua sisi yang saling mendukung (integral-fungsional) antara satu dengan lainnya. Apabila salah satu posisi tidak berfungsi maka dapat dipastikan posisi lainnya menjadi tidak berguna, sehingga keduanya harus saling menunjang dan melengkapi. Begitupun dalam perjanjian baku, para pihak harus menyadari bahwa keduanya saling ketergantungan dan saling membutuhkan, sehingga jalinan hukum yang dibangun idealnya dalam bingkai symbiosis mutualisme bukan dalam nuansa agar eksitensi masing-masing tetap bertahan. Ironisnya, secara das sein, jalinan perjanjian baku yang dirajut lebih "bernuansa" dominasi kepentingan salah satu pihak yang lebih unggul dibandingkan membangun kemitraan berkesinambungan sesuai asas kebebasan berkontrak ${ }^{31}$.

Bentuk klausula yang memberatkan diantaranya seperti penentuan suku bunga sepihak, penetapan nilai jaminan yang lebih tinggi dari pinjaman kredit, dan cicilan yang melampaui kemampuan finansial dianggap merugikan debitur karena beban yang harus ditanggung dari pelaksanaan perjanjian kredit. Klausula yang demikian sebagaimana dikemukakan Posner bahwa manusia sebagai makhluk hidup adalah homo economicus, artinya dalam mengambil tindakan untuk pemenuhan kebutuhan ekonominya, mereka mengedepankan nilai ekonomis dengan alasanalasan dan pertimbangan ekonomis. ${ }^{32}$ Serta berkenaan dengan dibuatnya perjanjian secara sepihak tanpa mengikutsertakan pihak debitur, maka membuat kedudukan kreditur sebagaimana "Legio Particuliere Wetgever". ${ }^{33}$

Konsep

penyalahgunaan keadaan sebagai alasan pembatalan

31 Ronald Saija, 'Penyalahgunaan Keadaan Oleh Negara dalam Praktik Perjanjian Pada Kajian Hukum Privat' (2016) 38 (3) Jurnal Kertha Patrika 181, 182.

$32 \quad$ Fajar Sugianto, Economic Analysis of Law (Kencana Prenada Media Group 2013) 28.

33 Mariam Darus Badrulzaamman, Perjanjian Kredit Bank (Alumni 1989) 33. 
perjanjian dalam kaitannya dengan permasalahan perjanjian kredit merupakan suatu bentuk kekeliruan bila hanya diamati dari sudut pandang bentuk perjanjian bakunya. Perjanjian baku akan selalu menimbulkan bergaining position yang tidak seimbang, bila setiap perjanjian baku akan dinilai sebagai penyalahgunaan keadaan lalu mengapa perjanjian baku masih sangat eksis diterapkan dalam berbagai jenis perjanjian? Sulitnya mengidentifikasi penyalahgunaan keadaan adalah karena konsep penyalahgunaan keunggulan ekonomi akan selalu bersinggungan dengan bergaining power.

Penyalahgunaan keunggulan ekonomi ini selalu terkait dengan bargaining power, inti penyalahgunaan keunggulan ekonomis ini terletak pada adanya inequality of bargaining power yang harus dihadapi oleh pihak yang lemah dan tidak dapat dihindari, sehingga tidak tercipta good-faith bargaining. ${ }^{34}$ Pihak yang kedudukan ekonominya kuat dapat "memaksakan" suatu klausul atau keseluruhan substansi perjanjian untuk ditandatangani.

Ketidakseimbangan kondisi yang terjadi dan adanya kebutuhan yang mendesak untuk mengadakan perjanjian dengan pihak yang memiliki keunggulan ekonomi unggul itu membuat pihak yang lemah membuat perjanjian dan menerima syarat yang diperlukan, tanpa adanya alternatif lain, walaupun sebenarnya disini bila perjanjian itu tidak ditandatangani maka tidak akan merugikan si pihak yang lemah.
Sedangkan dalam perjanjian kredit perbankan, bergaining power digunakan kreditur dengan mencantumkan beberapa klausula yang bersifat eksonerasi dilakukan karena bank secara sadar memahami bahwa untuk memberikan kredit atau pembiayaan sejenis adalah tindakan yang memiliki risiko tinggi, maka tindakan tertentu yang ditetapkan melalui klausula baku dijadikan bank sebagai upaya preventif atas kemungkinan resiko yang diderita tanpa bermaksud menyalahgunakan kekuasaannya untuk memaksa debitur.

Kendati demikian, unsur bargaining position yang tidak seimbang, meskipun dapat ditoleransi namun tidak menutup kemungkinan terjadinya penyalahgunaan keunggulan ekonomi kreditur pada saat praperjanjian maupun pelaksanaan perjanjian. Hal ini dapat ditemukan dalam beberapa putusan pengadilan yang memaparkan fakta mengenai penyalahgunaan keadaan kreditur pada saat pelaksanaan perjanjian kredit dengan caracara yang curang dan tidak beritikad baik sehingga berdampak merugikan debitur.

Kedudukan kreditur yang lebih unggul sejatinya memberikan peluang bagi kreditur untuk meraup keuntungan yang tidak lazim. Sepatutnya mengenai perubahan atau tindakan apapun (seperti menaikkan suku bunga/menetapkan nilai denda) yang dilakukan pada saat pelaksanaan perjanjian haruslah dipaparkan terlebih dahulu kepada debitur secara jelas dan terperinci. Hal ini dimaksudkan untuk memberi kesempatan pada debitur untuk berdiskusi atau

\footnotetext{
34 Good-Faith Bargaining is a negotiation between an employer and a representative of employees. A union, in which both parties meet and confer at reasonable times with open minds and with a view to reaching an agreement. Garner (n 9) 762.
} 
bernegosiasi mengenai perubahan tersebut. 35

Perbuatan menutup ruang negosiasi ulang merupakan perbuatan yang melanggar asas fairness dimana oleh karena suatu perjanjian dibuat untuk kepentingan semua pihak, maka perjanjian tersebut harus dibuat dengan mengindahkan dan memperhatikan kepentingan dari pihak-pihak yang tersangkut. ${ }^{36}$ Dalam konsep fairness, bank harus senantiasa memperhatikan kepentingan seluruh stakeholders berdasarkan asas kesetaraan dan kewajaran (equal treatment) dan bank harus memberikan kesempatan kepada seluruh stakesholders untuk memberikan masukan dan menyampaikan pendapat bagi kepentingan bank serta mempunyai akses terhadap informasi sesuai dengan prinsip keterbukaan. ${ }^{37}$

\section{Kekeliruan Interpretasi Penyalah- gunaan Keadaan Pada Perjanjian Kredit Perbankan}

Penyalahgunaan keadaan bukan hal baru dalam hukum perjanjian. Penyalahgunaan tidak dapat dibenarkan, akan tetapi cara mengkonstruksikannya dahulu dan kini yang berbeda. Awalnya penyalahgunaan keadaan dikonstruksikan sebagai perbuatan yang bertentangan dengan ketertiban umum atau tata krama yang baik (good zeden) atau kesusilaan sehingga berkaitan dengan cacat kausa perjanjian. Perjanjian yang lahir dalam kondisi psikologis ataupun ekonomis yang tidak berimbang dapat menyebabkan salah satu pihak terpaksa menutup perjanjian dengan prestasi yang tidak berimbang.

Perkembangan ilmu hukum menemukan titik kejanggalan dari prinsip penyalahgunaan keadaan yang persoalannya terletak pada konsekuensi dari cacat kausa, yakni perjanjian batal demi hukum untuk seluruhnya. Perjanjian batal demi hukum berarti perjanjian itu dianggap tidak pernah ada. ${ }^{38} \mathrm{Hal}$ ini dipandang tidak tepat karena pihak yang dirugikan memandang perjanjian yang diklaim tidak adil hanyalah sebagian klausul tertentu saja, bukan seluruh isi perjanjiannya. Perjanjian juga menjadi dapat dimintakan pembatalan oleh kedua belah pihak termasuk pihak yang menyalahgunakan keadaan apabila dianggap perjanjian tersebut ternyata merugikannya. Keadaan ini justru bertentangan dengan prinsip kepatutan, klaim penyalahgunaan keadaan justru menjadi alat untuk mempermainkan dan memanfaatkan perjanjian yang disepakati.

Perjanjian kredit yang digunakan dalam dunia perbankan dibuat dengan akta otentik demi menjamin kepastian hukum bagi para pihak. Akta otentik

35 J. Satrio menjelaskan ada tiga macam pembaharuan utang berdasarkan Pasal 1413 KUHPerdata: 1. Penggantian perikatan lama dengan baru untuk orang yang mengutangkan (novasi objektif); 2. debitur baru ditunjuk untuk menggantikan debitur lama (novasi subjektif pasif); 3. peristiwa di mana kreditur baru ditunjuk menggantikan kreditur lama (novasi subjektif aktif)". J. Satrio, Cessie, Subrogatie, Novatie, Kompensatie, dan Percampuran Hutang (cet. 2, Alumni 1999) 102-103.

Djuhaendah Hasan, Pengkajian Masalah Hukum Kebebasan Berkontrak dan Perlindungan yang Seimbang Bagi Para Pihak Dalam Perjanjian Kredit Bank di Indonesia (Badan Pembinaan Hukum Nasional, Departemen Kehakiman dan HAM RI 2002) 25.

37 Yunus Husein, Analisis dan Evaluasi Hukum Tentang Perubahan Undang-Undang Perbankan (UU No. 7/1992 Jo. UU No. 10 / 1998) (Badan Pembinaan Hukum Nasional, Departemen Kehakiman dan HAM RI 2007) 46.

38 Bernadeta Resti Nurhayati, 'Penyalahgunaan Keadaan Sebagai Dasar Pembatalan Perjanjian' (2019) 5 (1) Jurnal Komunikasi Hukum 1, 5. 
bermakna bahwa perjanjian kredit ialah perjanjian tertulis yang memuat klausul-klausul baku. Keharusan hubungan kredit bank berdasarkan perjanjian tertulis juga dapat dikaitkan dengan Instruksi Presedium Kabinet No. 15/EK/IN/10/1966 tanggal 3 Oktober 1966 Jo. Surat Edaran Bank Negara Indonesia Unit 1 No. 2/539/UPK/Pemb. Tanggal 20 Oktober 1967, yang menentukan bahwa dalam memberikan kredit dalam bentuk apapun bank-bank wajib membuat atau mempergunakan perjanjian kredit. Oleh karena itu perjanjian kredit selalu identik dengan perjanjian baku yang memuat klausula-klausula baku.

Perjanjian baku dan penyalahgunaan keadaan merupakan permasalahan yang selalu menjadi perdebatan karena keduanya memiliki kausalitas yang sangat erat. Perjanjian baku sering dianggap sebagai bentuk penyalahgunaan keadaan salah satu pihak yang berjanji. Konsep penyalahgunaan keadaan mengarah pada keunggulan ekonomis dan psikologis dari kreditur lebih dominan sehingga mempengaruhi debitur untuk memutuskan kehendaknya secara irasional. Penyalahgunaan keadaan timbul karena adanya ketidakseimbangan para pihak dalam suatu perjanjian yang menimbulkan tidak bebasnya salah satu pihak, yakni pihak dengan kedudukan yang lebih rendah, untuk mengutarakan kehendaknya dalam suatu perjanjian. ${ }^{39}$

Kaitan penyalahgunaan keadaan dengan perjanjian baku terletak pada kedudukan tidak seimbang yang ditimbulkan. Klausula baku yang dibuat sepihak oleh kreditur mengakibatkan tidak adanya proses tawar dan negosiasi dalam perjanjian. Hilangnya proses tersebut berakibat pada kedudukan debitur lebih rendah sehingga debitur tidak memiliki kesempatan untuk merubah atau menegosiasikan isi perjanjian kredit. Hal ini secara tidak langsung menimbulkan penafsiran bahwa kesepakatan debitur berada di bawah pengaruh bayang-bayang kreditur yang seringkali dikaitkan dengan penyalahgunaan keadaan.

Keadaan yang menyoroti penderitaan debitur akan beban yang ditanggung akibat terikat kewajiban perjanjian kredit menyebabkan kesalahan penggunaan prinsip penyalahgunaan keadaan. Kesalahan tersebut diwujudkan dalam bentuk ajuan gugatan ke pengadilan dengan dalil penyalahgunaan keadaan pada perjanjian kredit. Sayangnya upaya hukum yang bertujuan untuk memperoleh keadilan dan perlindungan secara hukum ini justru mengandung kekeliruan, yakni pada anggapan bahwa unsur penyalahgunaan keadaan terdapat pada isi perjanjian kredit.

Berikut ulasan beberapa putusan pengadilan yang memutus perkara mengenai pembatalan perjanjian kredit dengan dalil penyalahgunaan keadaan.

1) Putusan Nomor: 297/Pdt.G/ 2014/PN.Smg (War vs PT. BPR Mandiri Arta Abadi)

a) Duduk Perkara

Perjanjian kredit nomor 45 Tertanggal 30 Agustus 2010 dengan jumlah pinjaman Rp. 65.000.000. Penggugat bangkrut, berhenti membayar kredit dan menerima pemberitahuan lelang agunan. Sisa tunggakan tertang- 
gal 19 Juli 2012 (somasi I) adalah sebesar Rp. 16.396.821,01 tetapi pada 14 April 2014 (somasi II) sisa tunggakan melonjak menjadi Rp. 145.746.571,92.

b) Dalil penyalahgunaan keadaan Tergugat melakukan penyalahgunaan keadaan dengan menetapkan besaran denda yang tidak patut. Tempo cicilan seharusnya berakhir tanggal 30 Agustus 2013 tapi Tergugat tetap menghitung bunga dan denda sampai 14 April 2014 hingga mencapai Rp. 131.899.482.

c) Pertimbangan Majelis Hakim

Majelis Hakim memandang Pengenaan Denda yang sangat besar tanpa perincian adalah suatu penyalahgunaan keadaan Tergugat.

2) Putusan Nomor: 09/Pdt.G/ 2017/PN.Pwk jo. Nomor: 525/PDT/2017/PT.BDG

a) Duduk Perkara

Perjanjian kredit nomor 1153005008930 mengikat kedua belah pihak tertanggal 14 Feb 2012. Tergugat dianggap melakukan PMH karena mencantumkan klausula baku yang dilarang UUPK menyebabkan Tergugat menerbitkan Sertifikat Hak Tanggungan yang merugikan Penggugat.

b) Dalil Penyalahgunaan Keadaan Penggugat dalam memori banding mengklaim terpaksa menandatangani perjanjian a quo karena masalah keuangannya dan Tergugat diklaim memanfaatkan hal tersebut dengan penyalahgunaan keunggulan ekonomi.

c) Pertimbangan Majelis Hakim

Majelis Hakim PN menyatakan perjanjian tidak bertentangan dengan ketentuan Pasal 18 UUPK, dan perjanjian adalah sah. Majelis Hakim PT menguatkan putusan PN dan menolak memori banding untuk seluruhnya (tidak mempertimbangkan dalil Penggugat mengenai penyalahgunaan keadaan).

3) Putusan Nomor: 37/Pdt.G/ 1998/PN.GS jo. Nomor 628/ Pdt/1999/PT.Sby jo. Nomor: $3956 \mathrm{~K} / \mathrm{Pdt} / 2000$ SG, AK vs Bank X ${ }^{40}$

a) Duduk Perkara

Perjanjian kredit dengan pinjaman sebesar Rp. 1.850.000.000 mengandung klausula baku dengan bunga $21 \%$.

b) Dalil Penyalahgunaan Keadaan Dalam pelaksanaan perjanjian Penggugat mengklaim telah terjadi penyalahgunaan keadaan tergugat yang menaikkan suku bunga dari $21 \%$ menjadi $69 \%$ tanpa sepengetahuan penggugat.

c) Pertimbangan Majelis Hakim

Majelis hakim memutuskan terjadi penyalahgunaan keadaan dalam penentuan kenaikan bunga. Majelis hakim berpendapat perbuatan tergugat menaikkan suku bunga saat krisis moneter adalah perilaku semenamena tanpa mengindahkan norma kepatutan, keadilan dan kelayakan.

Ulasan rangkaian putusan di

40 Amin Imanuel Bureni, 'Asas Keseimbangan dalam Perjanjian Kredit Bank (Studi Terhadap Putusan Mahkamah Agung RI No. 3956 K/Pdt/2000 jo. Putusan Pengadilan Tinggi SBY No. 628/Pdt/1999/PT.SBY jo. Putusan Pengadilan Negeri GS No. 37/Pdt.G/1998/PN.GS)' (Tesis, Universitas Indonesia 2013). 
atas membuktikan bahwa terdapat upaya hukum melalui jalur pengadilan yang digunakan debitur untuk membatalkan perjanjian dengan dalil penyalahgunaan keadaan. Meskipun gugatan dapat diajukan dalam proses peradilan, ternyata hasilnya tidak terlalu berbuah manis. Rata-rata gugatan perbuatan melawan hukum dengan penyalahgunaan keadaan untuk pembatalan perjanjian kredit memuat putusan yang ditolak atau tidak diterima. Ketiga putusan di atas memaparkan poin pertimbangan hakim dalam memutus perkara pembatalan perjanjian dengan alasan penyalahgunaan keadaan. Persamaannya terletak pada petitum majelis hakim yang tidak membatalkan perjanjian, melainkan hanya memutus pembatalan terhadap perilaku debitur yang terduga menyalahgunakan keadaan pada saat pelaksanaan perjanjian kredit.

Dalam sistem peradilan Indonesia, majelis hakim cenderung mempertimbangkan dan menganalisis gugatan penyalahgunaan keadaan melalui perbuatan nyata yang dilakukan pihak tergugat, karena dapat menentukan nilai kebenaran atas penyalahgunaan keadaan yang didalilkan. Hal ini yang menyebabkan dalil penyalahgunaan keadaan dengan dasar pencantuman perjanjian baku menjadi sulit dikabulkan. Model seperti ini secara tidak langsung menjadi prinsip yang dianut peradilan Indonesia dalam memutus perkara tentang penyalahgunaan keadaan dalam perjanjian.

Berbagai putusan pengadilan tersebut membuktikan bahwasanya penyalahgunaan keadaan tidak dapat serta merta diajukan karena cacat kausa. Dengan kata lain, isi perjanjian tidak mempengaruhi perilaku penya- lahgunaan keadaan yang didalilkan pada kreditur. Hal ini tidak selaras dengan pandangan debitur yang selama ini menganggap kesewenangan pihak kreditur mencantumkan klausul adalah tindakan penyalahgunaan keadaan. Kekeliruan yang dipahami mengenai penyalahgunaan keadaan oleh masyarakat umum terkadang disalahgunakan dan dijadikan sebagai pedoman berperkara di pengadilan.

\section{Interpretasi yang Seharusnya Mengenai Penyalahgunaan Keadaan Pada Perjanjian Kredit Perbankan}

Pada hakekatnya penyalahgunaan keadaan tidak semata berkaitan dengan isi perjanjian yang tidak berimbang. Perjanjian dianggap bertentangan dengan tata krama/ kesusilaan atas dasar adanya penyalahgunaan keadaan yang mengiringi terjadinya perjanjian tersebut. Penyalahgunaan keadaan dikategorikan sebagai tindakan yang mengakibatkan cacat kehendak karena bersinggungan dengan proses terjadinya kesepakatan/persetujuan ketika mengadakan perjanjian.

Pihak yang memiliki keunggulan posisi tawar akan memiliki kemampuan mendominasi dan mempengaruhi kehendak lawan berjanjinya, sehingga pihak lain terpaksa mengadakan perjanjian tersebut. Keunggulan posisi tawar ini tentunya bermuara pada pengaruh ekonomi. Posisi kreditur yang secara ekonomi kuat memberikan peluang untuk menyalahgunakan kekuasaan ekonomi (misbruik van economisch overwicht) yang berimbas pada semakin lemahnya posisi debitur. Padahal, kehendak bebas para pihak dalam menentukan isi perjanjian merupakan hal terpenting sebagai salah satu 
syarat sahnya perjanjian. ${ }^{41}$

Sebagaimana paradigma interpretatif, dalam memaknai disclaimer penyalahgunaan pada perjanjian kredit sebaiknya perlu ditelaah dulu mengenai seluk beluk perjanjian kredit tersebut. Pemberian kredit melalui perjanjian kredit dilakukan oleh bank untuk meningkatkan volume bisnisnya. Dalam kebijakan pembiayaan bank harus ditetapkan pokok pengaturan mengenai tata cara pemberian kredit atau pembiayaan kepada pihak terkait dengan Bank dan debitur tertentu, Dalam Pasal 8 UU Perbankan ditentukan bahwa:

a) Dalam memberikan kredit atau pembiayaan berdasarkan prinsip syariah, bank umum wajib mempunyai keyakinan berdasarkan analisis yang mendalam atau itikad baik dan kemampuan serta kesanggupan nasabah debitor untuk melunasi utangnya atau mengembalikan pembiayaan dimaksud sesuai dengan yang diperjanjikan.

b) Bank umum wajib memiliki dan menerapkan pedoman perkreditan dan pembiayaan berdasarkan prinsip syariah, sesuai dengan ketentuan yang ditetapkan oleh Bank Indonesia.

Hakekat UU adalah umum dan abstrak, maka sudah sepatutnya ketentuan di atas perlu didukung dengan hal-hal yang bersifat implementatif dan konkret. Sebagai sumber pendapatan utama bank dengan high risk, maka setiap persetujuan kredit harus memperhatikan prinsip perkre- ditan yang sehat. Prinsip-prinsip yang harus diterapkan bank untuk meminimalisir tingkat resiko kredit diantaranya: 42

a) Prinsip Kepercayaan

Prinsip kepercayaan melandasi hubungan antara bank dan nasabah bank. Bank berusaha menghimpun dana masyarakat yang disimpan berdasarkan kepercayaan, sehingga setiap bank perlu menjaga kesehatan banknya dengan tetap memelihara dan mempertahankan kepercayaan masyarakat. Prinsip kepercayaan diatur dalam Pasal 29 ayat (4) UU Perbankan yang menyatakan bahwa untuk kepentingan nasabah, maka bank wajib menyediakan informasi mengenai adanya kemungkinan yang menimbulkan resiko kerugian sehubungan dengan transaksi nasabah yang dilakukan melalui bank. ${ }^{43}$

b) Prinsip Kehati-hatian

Prinsip kehati-hatian adalah satu prinsip yang menegaskan bahwa bank dalam menjalankan kegiatan usaha baik dalam penghimpunan terutama dalam penyaluran dana kepada masyarakat harus sangat berhati-hati. Tujuan dilakukannya prinsip ini agar bank selalu dalam keadaan sehat menjalankan usahanya dengan baik dan mematuhi ketentuan dan norma hukum yang berlaku di dunia perbankan. ${ }^{44}$

\footnotetext{
41 Sutedjo Bomantoro, 'Implementasi Doktrin Penyalahgunaan Keadaan dalam Perjanjian dalam Praktek Peradilan di Indonesia' (Tesis, Universitas Islam Indonesia 2004).

42 Detisa Monica Podung, 'Kredit Macet dan Penerapan Prinsip Kehati-Hatian dalam Perbankan' (2016) 5 (3) Jurnal Lex Crimen 50-52.

43 Sentosa Sembiring, Hukum Perbankan (ed. revisi, Mandar Maju 2012) 234.

$44 \quad$ Podung (n 42) 50.
} 
c) Prinsip Kerahasian

Diatur dalam Pasal 40-44 A UU Perbankan. Ketentuan ini mewajibkan bank untuk merahasiakan keterangan mengenai nasabah penyimpan dan simpanannya. Namun dalam ketentuan tersebut kewajiban merahasiakan itu bukan tanpa pengecualian. Kewajiban merahasiakan itu dikecualikan untuk dalam hal kepentingan pajak, penyelesaian utang piutang bank yang sudah diserahkan kepada Badan Urusan Piutang dan Lelang/ Panitia Urusan Piutang Negara, untuk kepentingan pengadilan perkara pidana, dalam perkara perdata antara bank dengan nasabah, dan dalam rangka tukar menukar informasi antar bank. 45

d) Prinsip Mengenal Nasabah

Penerapan prinsip mengenal nasabah atau lebih dikenal umum dengan 'know your customer principle' (KYC principle) ini didasari pertimbangan bahwa prinsip mengenal nasabah tidak saja penting dalam rangka pemberantasan kejahatan pencucian uang, tetapi juga dalam rangka penerapan prudential banking untuk melindungi bank atau perusahaan jasa keuangan lain dari berbagai resiko dalam berhubungan dengan nasabah dan counter party. Khususnya terhadap para nasabah, pihak bank, atau perusahaan jasa keuangan lain harus mengenali para nasabah agar bank atau perusahaan jasa keuangan lain tidak terjerat di dalam kejahatan pencucian uang. 46

Keempat prinsip perkreditan di atas pada dasarnya menekankan pada upaya bank dalam meninjau dan menganalisis calon debitur sebelum mengikatkan diri dalam sebuah perjanjian kredit. Meski prinsip tersebut ditujukan untuk dilaksanakan oleh bank, namun manfaatnya juga dapat dirasakan oleh pihak debitur. Dengan informasi yang mumpuni, kesepakatan yang lahir dari perikatan kredit pun dapat terjamin akuntabilitasnya. Dalam artian bahwa perjanjian kredit lahir berdasarkan prinsip-prinsip yang berlandaskan asas itikad baik kreditur terhadap debitur.

Penyelenggaraan kredit melalui perbankan dengan berdasar pada itikad baik sesuai amanat UU selain untuk meminimalisir tingkat resiko juga merupakan hal tepat untuk mencegah pola-pola cacat kehendak yang berakibat pada penyalahgunaan keadaan. Kedudukan yang tidak seimbang antara kreditur dan debitur memang diakui memberi potensi penyelewengan oleh pihak yang lebih dominan. Namun hal ini dapat diantisipasi melalui peraturan-peraturan sebagai pelindung bagi para pihak.

Konteksnya perlu dipahami kembali mengenai perjanjian kredit dan bagaimana tafsir penyalahgunaan keadaan tersebut dapat dimasukan sebagai perbuatan melawan hukum kreditur. Seperti yang telah diungkapkan sebelumnya bahwa dalil penyalahgunaan keadaan kini mengalami pergeseran, bukan lagi melihat pada isi perjanjian melainkan harus

\footnotetext{
45 Ibid.

46 Adrian Sutedi, Hukum Perbankan, Suatu Tinjauan Pencucian Uang, Merger, Likuidasi dan Kepailitan (Sinar Grafika 2014) 72-73.
} 
didasarkan pada tindakan atau perbuatan tertentu yang terkategori sebagai cacat kehendak. Oleh karena itu, mengkaitkan perjanjian baku dengan penyalahgunaan keadaan adalah hal yang tidak dibenarkan.

Penerbitan perjanjian kredit dengan muatan klausula baku sebenarnya merupakan upaya pelayanan praktis, efisien dan efektif yang tetap berlandaskan pada asas kebebasan berkontrak. Namun penerapan perjanjian baku ini seringkali dianggap sebagai sebuah pelanggaran terhadap asas kesepakatan, karena perjanjian dibuat sepihak dan pihak lain hanya perlu menandatangani tanpa berhak merubah isi perjanjian tersebut. Keadaan semacam ini tentu melemahkan posisi salah satu pihak, tetapi menjadi tidak dihiraukan oleh pihak yang bersangkutan karena adanya hal tertentu yang lebih penting yang membuatnya terpaksa mengikatkan diri terhadap perjanjian baku yang ditawarkan, seperti desakan kebutuhan atau desakan finansial.

Hal di atas bukan berarti dalam perjanjian kredit tidak akan terjadi penyalahgunaan keadaan. Perbuatan melawan hukum dengan penyalahgunaan keadaan dalam perjanjian kredit tetap dimungkinkan terjadi asalkan unsur esensialitas dari penyalahgunaan keadaan dapat dibuktikan debitur di persidangan. Majelis hakim selalu mempunyai tolak ukur yang pasti dalam memutus perkara mengenai dalil penyalahgunaan keadaan dalam perjanjian kredit meskipun secara yuridis belum ada pengaturannya. Tolak ukur ini berpedoman pada karakteristik penyalahgunaan keadaan yang dilihat melalui perbuatan yang terkategori sebagai cacat kehendak.
Sebagaimana lazimnya dalam tuntutan pembatalan perjanjian atas dasar cacat kehendak, maka tidak diperlukan unsur kerugian. Sudah cukup apabila dapat dibuktikan bahwasanya tanpa adanya penyalahgunaan keadaan, perjanjian tidak mungkin lahir. Penyalahgunaan keadaan sebagai alasan pembatalan perjanjian dapat dilakukan bilamana dapat dibuktikan cacat kehendak yang dilakukan salah satu pihak pada saat proses kesepakatan perjanjian kredit. Sebaliknya, penyalahgunaan keadaan tidak dapat dijadikan alasan pembatalan perjanjian bila hanya mendalilkan isi perjanjian sebagai itikad buruk kreditur yang dapat merugikan debitur. Karena hakikat dari penyalahgunaan keadaaan adalah faktor cacat kehendak, bukan pada isi/kausa perjanjian.

\section{PENUTUP}

Penyalahgunaan keadaan merupakan suatu doktrin yang muncul dari sistem common law inggris. Lahir dari yurisprudensi hakim yang menemukan keadaan diluar dari kepatutan dan kebiasaan. Eksistensinya kian berkembang selaras dengan semakin maraknya keluhan dan kerugian pihak-pihak dalam balutan perjanjian. Tidak berbeda halnya dengan perjanjian kredit yang memunculkan persoalan terhadap keberadaan fungsi klausula baku yang merupakan bagian dari isi perjanjian kredit perbankan. Fenomena gugatan dengan dalil penyalahgunaan keadaan dalam perjanjian kredit pun akhirnya banyak diterapkan oleh debitur untuk menuntut ganti kerugian.

Ada beberapa hal yang perlu dipahami sebelum mendalilkan suatu perjanjian mengandung penyalahgu- 
naan keadaan. Pada perjanjian kredit keadaan kreditur yang menetapkan klausula baku dan membuat perjanjian kredit dengan bentuk perjanjian baku tidak dapat dikategorikan sebagai penyalahgunaan keadaan, karena perbuatan tersebut merupakan amanat UU. Selain itu bargaining power yang tidak seimbang antara debitur dan kreditur merupakan hal yang tidak dapat dihindari. Sebaliknya ketidakberdayaan debitur juga tidak boleh disalahgunakan akibat keunggulan ekonomis, karena kreditur harus berpedoman pada prinsip perkreditan yang sehat.

Penyalahgunaan keadaan sarat dengan konsep cacat kehendak, dan tidak mengharuskan adanya cacat kausa. Pemahaman ini yang seringkali gagal dimengerti oleh masyarakat pada umumnya. Selama ini gugatan hukum yang diajukan atas penyalahgunaan keadaan dalam perjanjian kredit hanya berpatokan pada kausa/isi perjanjian. Oleh sebab itu, rata-rata gugatan dengan dalil penyalahgunaan keadaan banyak ditolak oleh majelis hakim, karena ketidaksesuaian unsur perbuatan dengan gugatan yang didalilkan. Akan tetapi penyalahgunaan keadaan tetap dapat dimungkinkan terjadi pada perjanjian kredit. Hal ini terjadi bilamana perilaku kreditur saat praperjanjian maupun saat pelaksanaan perjanjian terbukti melakukan cacat kehendak.

Selain itu untuk memberikan kepastian hukum dalam berbagai hal yang terkait dengan dalil penyalahgunaan keadaan, maka baiknya perlu segera ditetapkan regulasi yang mengatur khusus tentang karakteristik dan penggunaan penyalahgunaan keadaan. Hal ini sudah sepatutnya dilakukan karena pada era modern business ini sangat potensial terjadi perbuatan-perbuatan penyalahgunaan keadaan.

\section{DAFTAR BACAAN}

\section{Buku}

Badrulzaamman MD, Perjanjian Kredit Bank (Alumni 1989).

Cracknell DG, Obligation: Contract Law (Old Bailey Press 2003).

Dyson A, Goudkamp J and WilmotSmith F (eds) Defences in Contract (Hart Publishing 2017).

Hasan D, Pengkajian Masalah Hukum Kebebasan Berkontrak dan Perlindungan yang Seimbang Bagi Para Pihak Dalam Perjanjian Kredit Bank di Indonesia (Badan Pembinaan Hukum Nasional, Departemen Kehakiman dan HAM RI 2002).

Husein Y, Analisis dan Evaluasi Hukum Tentang Perubahan Undang-Undang Perbankan (UU No. 7/1992 Jo. UU No. 10 /1998) (Badan Pembinaan Hukum Nasional, Departemen Kehakiman dan HAM RI 2007).

Kasmir, Manajemen Perbankan (cet. 2, RajaGrafindo Persada 2008).

Marzuki PM, Penelitian Hukum (ed. revisi, Kencana Prenada Media Group 2013).

Satrio J, Cessie, Subrogatie, Novatie, Kompensatie, dan Percampuran Hutang (cet. 2, Alumni 1999).

Sembiring S, Hukum Perbankan (ed. revisi, Mandar Maju 2012).

Soekanto S, Pengantar Penelitian Hukum (Rineka Cipta 1986).

Sutedi A, Hukum Perbankan, Suatu Tinjauan Pencucian Uang, Merger, Likuidasi dan Kepailitan (Sinar 
Grafika 2014).

Sugianto F, Economic Analysis of Law (Kencana Prenada Media Group 2013).

Widiowatie DS (tjm), Dasar-dasar Hukum Bisnis penerjemah (Nusa Media 2009).

\section{Artikel Jurnal}

Chen- Wishart M, 'Legal Transplant and Undue Influence: Lost in Translation or A Working Misunderstanding?' (2013) 62 (1) International and Comparative Law Quarterly.

Hartono A, 'Multi Paradigma dalam Penelitian Akuntansi; Suatu Tinjauan Konsep' (2012) 10 (1) Jurnal Ekulilibrium.

Ihromi TO, 'Paradigma Baru bagi Pengkajian Masalah Wanita dan Jender dalam Antropologi' (1999) 60 Jurnal Antropologi Indonesia.

Limpele MM, 'Perjanjian Kredit dengan Jaminan Hak Milik Atas Tanah dan Bangunan Pada Bank Tabungan Negara Cabang Manado Menurut UU No. 4 Tahun 1996 Tentang Hak Tanggungan' (2017) 6 (2) Jurnal Lex Crime.

Mardhati HU dan Saputra H, 'Penyalahgunaan Keadaan (Misbruik ban Omstandigheden) dalam Perjanjian Asuransi Melalui Telemarketing' (2019) 41

(2) Jurnal Kertha Patrika.

Martam NK, 'Tinjauan Yuridis tentang Rechtvinding (Penemuan Hukum) dalam Hukum Perdata Indonesia' (2018) 1 (1) Gorontalo Law Review.

Nurhayati BR, 'Penyalahgunaan Keadaan Sebagai Dasar Pemba- talan Perjanjian' (2019) 5 (1) Jurnal Komunikasi Hukum.

Paparang F, 'Misbruik van Omstandigheden dalam Perkembangan Hukum Perjanjian' (2018) 22 (2) Jurnal Hukum Unsrat.

Podung DM, 'Kredit Macet dan Penerapan Prinsip Kehati-Hatian dalam Perbankan' (2016) 5 (3) Jurnal Lex Crimen.

Putra FMK, 'Paksaan Ekonomi dan Penyalahgunaan Keadaan Sebagai Bentuk Cacat Kehendak Dalam Perkembangan Hukum Perjanjian' (2015) 30 (2) Jurnal Yuridika.

Satory A, 'Perjanjian Baku dan Perlindungan Konsumen dalam Transaksi Bisnis Sektor Jasa Keuangan: Penerapan dan Implementasinya di Indonesia' (2015) 2 (2) Padjadjaran Journal of Law.

Saija R, 'Penyalahgunaan Keadaan Oleh Negara dalam Praktik Perjanjian Pada Kajian Hukum Privat' (2016) 38 (3) Jurnal Kertha Patrika.

Setiawan AS, 'Penggunaan Metode Kuantitatif Adalah Paradigma Positivist' (2014) 12 (1) Jurnal Buletin Ekonomi.

Simanjuntak R, 'Akibat dan Tindakantindakan Hukum Terhadap Pencantumkan Klausula Baku dalam Polis Asuransi yang Bertentangan dengan Pasal 18 UU 8/1999 tentang Perlindungan Konsumen' (2003) 22 (2) Jurnal Hukum Bisnis.

Sulaiman, 'Paradigma Dalam Penelitian Hukum' (2018) 20 (2) Kanun Jurnal Ilmu Hukum. 


\section{Tesis/Disertasi}

Bomantoro M, 'Implementasi Doktrin Penyalahgunaan Keadaan dalam Perjanjian dalam Praktek Peradilan di Indonesia' (Tesis, Universitas Islam Indonesia 2004).

Bureni AI, 'Asas Keseimbangan dalam Perjanjian Kredit Bank (Studi Terhadap Putusan Mahkamah Agung RI No. 3956 K/Pdt/2000 jo. Putusan Pengadilan Tinggi SBY No. 628/Pdt/1999/PT.SBY jo. Putusan Pengadilan Negeri GS No. $\quad 37 /$ Pdt.G/1998/PN.GS)' (Tesis, Universitas Indonesia 2013).

Nuryani E, 'Klausula Baku yang Tidak Seimbang Dalam Perjanjian Kredit Bank dan Kaitannya dengan Perlindungan Konsumen' (Tesis, Universitas Indonesia 2009).

\section{Artikel/Makalah Ilmiah}

Harumita VS, 'Pentingnya Validitasi Data Pengajuan Kredit Pensiun Pada PT Bank Rakyat Indonesia Tbk: Kantor Cabang Kusuma Bangsa Surabaya' (Makalah, Fakultas Vokasi Universitas Airlangga 2015).

Puspitasari Z, 'Analisis Yuridis Perlindungan Hukum Bagi Nasabah Kredit Perbankan dari Penyalahgunaan Keadaan Dalam Perjanjian Baku (Tinjauan Yuridis Undang-Undang Nomor 8 Tahun 1999 Tentang Perlindungan Konsumen)' (Artikel Ilmiah, Fakultas Hukum Universitas Brawijaya 2014).

\section{Kamus}

Garner BA (ed), Black's Law Dictionary (9th edn, West Group 2009).

\section{Putusan Pengadilan}

War vs PT. BPR Mandiri Arta Abadi, Nomor 297/Pdt.G/2014/PN. Smg, Pengadilan Negeri Semarang.

Endang Harun vs PT. Bank Mega, Tbk., Nomor 09/Pdt.G/2017/PN. Pwk, Pengadilan Negeri Purwakarta, 20 September 2017.

Endang Harun vs PT. Bank Mega, Tbk., Nomor 525/Pdt/2017/PT. Bdg, Pengadilan Tinggi Bandung, 23 Januari 2018.

SG, AK vs Bank X, Nomor 37/ Pdt.G/1998/PN.GS, Pengadilan Negeri Gresik.

SG, AK vs Bank X, Nomor 628/Pdt/ 1999/PT.Sby, Pengadilan Tinggi Surabaya, 4 Maret 2000.

SG, AK vs Bank X, Nomor 3956 K/ Pdt/2000, Putusan Mahkamah Agung Republik Indonesia, 23 September 2003.

\section{Peraturan Perundang-Undangan}

Kitab Undang-Undang Hukum Perdata.

Undang-Undang Nomor 10 Tahun 1998 tentang Perbankan.

Undang-Undang Nomor 8 Tahun 1999 tentang Perlindungan Konsumen. 